\title{
GM crop cultivation surges, but novel traits languish
}

Wayne Peng

Total planting area for transgenic crops exceeded 1 billion hectares in 2010. Syngenta's E3272 maize line, designed to facilitate biofuel production with a mutant alpha-amylase transgene, was approved in the US

\section{Global area by transgenic trait}

Crops with two or more stacked traits continue to be popular.

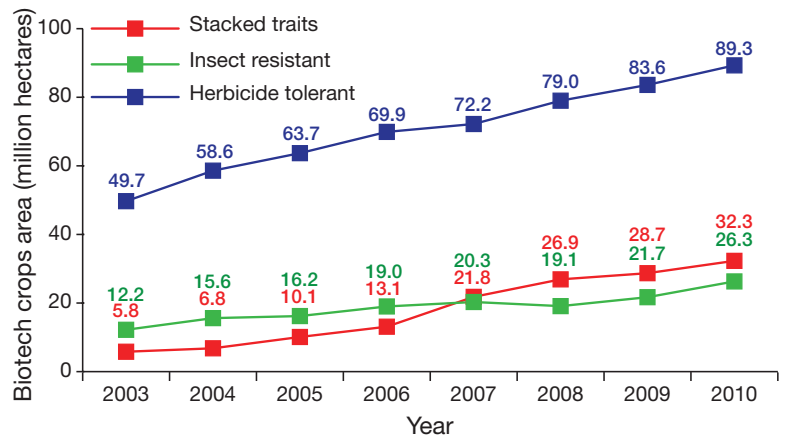

Source: International Service for the Acquisition of Agri-Biotech Applications.

\section{Global area of transgenic crops by country}

Since 2004, Brazil, South Africa and Canada have the highest average annual growth rate in hectarage: $33 \%, 38 \%$ and $76 \%$, respectively.

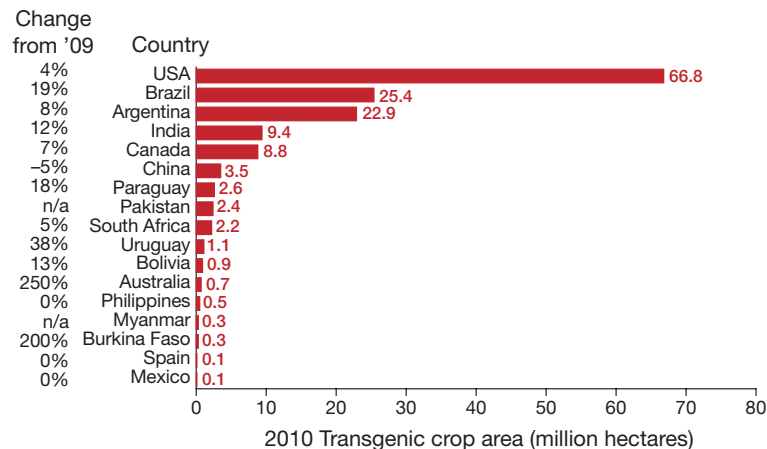

Source: International Service for the Acquisition of Agri-Biotech Applications.

\section{EU transgenic crop field trials}

There were 79 field trials in the EU, more than half of which were in Spain (data labeled), the 5th lowest number since 1991.

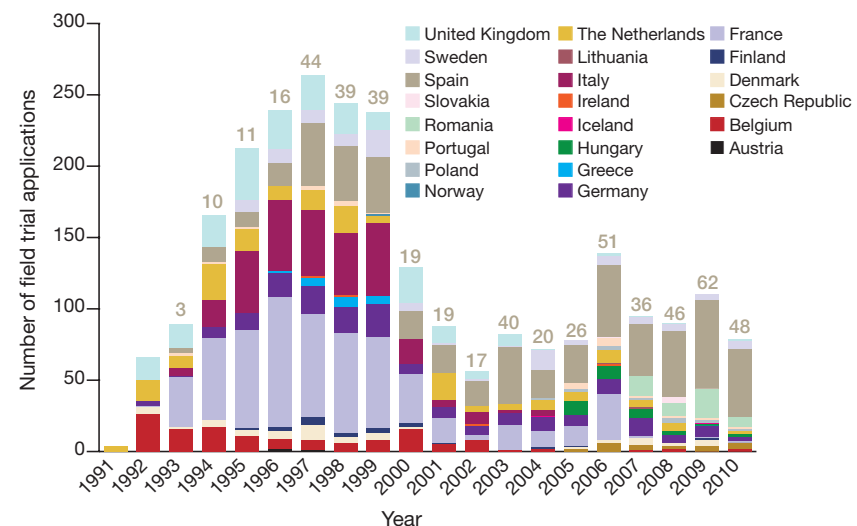

Source: European Commission Joint Research Center; <http://gmoinfo.jrc.ec.europa.eu/> earlier this year. Although new approvals and field trials slowed down in the US and Europe, food and feed uses of existing transgenic crops keep expanding in Brazil, the Philippines and Korea.

\section{Global area and value of transgenic crops}

Total global transgenic crop area exceeded 1 billion hectares since 1996.

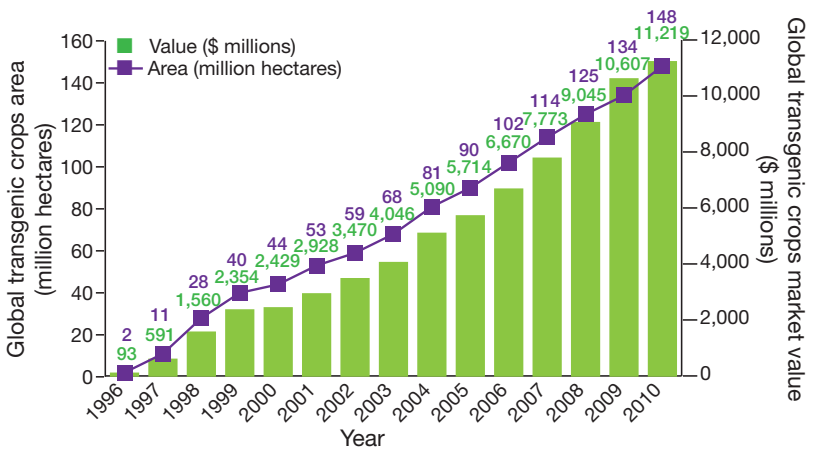

Source: International Service for the Acquisition of Agri-Biotech Applications. Value data are explicitly from seeds and licensing revenue rather than from 'crops' themselves.

\section{Transgenic crop adoption rate in the US}

Worldwide, canola hectarage jumped, but transgenic alfalfa and squash adoption remained flat. Transgenic papaya in Hawaii has grown by 11,000 hectares in the past 3 years.

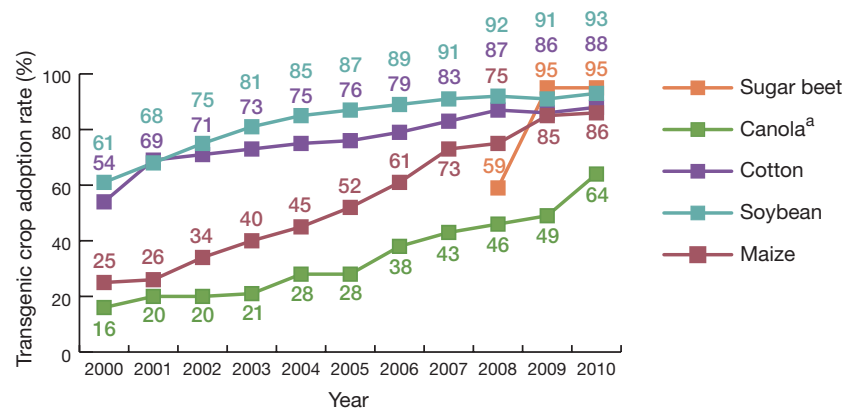

Source: International Service for the Acquisition of Agri-Biotech Applications; National Agricultural Statistics Service. ${ }^{\mathrm{a}}$ Global adoption rate.

Notable recent transgenic crop approvals

\begin{tabular}{|c|c|c|c|c|}
\hline unt & Crop & Company & Decision & Use \\
\hline US & Maize & Syngenta & $\begin{array}{l}\text { SYN-E3272-5. Transgenic maize line express- } \\
\text { ing a thermostable alpha-amylase enzyme } \\
\text { (AME797E) for use in ethanol production. }\end{array}$ & $\begin{array}{l}\text { Planting; } \\
\text { biofuel }\end{array}$ \\
\hline US & Maize & Syngenta & $\begin{array}{l}\text { SYN-IR162-4. Transgenic maize line express- } \\
\text { ing Bacillus thuringiensis Vip3Aa protein that } \\
\text { is toxic to several lepidoptera. }\end{array}$ & Planting \\
\hline US & Soybean & $\begin{array}{l}\text { Pioneer } \\
\text { Hi-Bred }\end{array}$ & $\begin{array}{l}\text { DP-305423-1. Transgenic soybean line with } \\
\text { a modified, noncoding omega-6 desaturase } \\
\text { gene (FAD2-1), expressed from seed-specific } \\
\text { promoter, resulting in increased levels of } \\
\text { monosaturated fatty acids (oleic) and reduced } \\
\text { polysaturated fatty acids (linoleic and linolenic). }\end{array}$ & Planting \\
\hline
\end{tabular}

Source: CERA (2010). GM Crop Database. Center for Environmental Risk Assessment (CERA), ILSI Research Foundation, Washington, DC. <http://cera-gmc.org/>

Wayne Peng is Emerging Technology Analyst at Nature Publishing Group 